\title{
PERANCANGAN KEY PERFORMANCE INDICATORS KINERJA SUPPLY CHAIN PT. XYZ DENGAN PENDEKATAN BALANCED SCORECARD
}

\author{
Joko Hardono \\ Program Studi Teknik Industri Universitas Muhammadiyah Tangerang \\ e-mail: jhardno@yahoo.com
}

\begin{abstract}
ABSTRAK
Pengukuran kinerja Supply Chain PT. XYZ hanya melihat dari produktivitas perusahaan. Produktivitas hanya mampu mengukur kinerja proses internal, pada proses internal dalam satu hubungan rantai pasok. Perusahaan perlu merancang model pengukuran kinerja supply chain secara keseluruhan dan terintegrasi dalam suatu hubungan kausal, mulai dari pemasok, proses internal kepada pelanggan, untuk mengetahui efektivitas perusahaan rantai pasokan. balanced scorecard memenuhi perspektif yang diperlukan. Model balanced scorecard digunakan sebagai kerangka kerja untuk merancang Key Performance Indicator (KPI) dari kinerja supply chain PT. XYZ. KPI adalah desain berdasarkan 4 perspektif, yaitu: proses internal, pelanggan, pembelajaran dan pertumbuhan dan perspektif keuangan. Pembobotan untuk menentukan prioritas antara perspektif dan KPI dilakukan dengan menggunakan Analytical Hierarchy Process (AHP). Hasil dari analisis dihasilkan 20 KPI. perspektif proses internal yang berisi 9 KPI dengan berat total 21,0\%, perspektif pelanggan berisi 6 KPI dengan berat total 42,6\%, Belajar dan perspektif pertumbuhan berisi 4 KPI dengan berat total 17,5\%, perspektif Pemegang Saham mengandung 1 KPI dengan total berat 19,0.
\end{abstract}

Kata kunci: Key Performance Indicator, Supply Chain, Balanced Scorecard, Analytical Hierarchy proceses

\begin{abstract}
Supply Chain performance measurement PT. XYZ had only seen from the productivity of the Companie. Productivity is only able to measure the performance of the internal process, while the internal process is but one link in the chain of Supply Chain. Companies need to design a model of supply chain performance measurement as a whole and integrated in a causal relationship, ranging from suppliers, internal processes to customers, in order to know the effectiveness of supply chain companies. Balanced scorecard meets the necessary perspective. Balanced scorecard model is used as a framework for designing of Key Performance Indicator (KPI) of supply chain performance PT. XYZ. KPI is design based on 4 perspectives, that is: internal processes, customers, learning and growth and perspective financial. Weighting to determine priorities between perspective and KPI performed using Analytical Hierarchy Process (AHP). Result from th eanalysis is generated $20 \mathrm{KPI}$. Internal process perspective contain 9 KPIs with total weight 21,0 \%, Customer perspective contain 6 KPIs with total weight 42,6\%, Learning and growth perspective contain 4 KPIs with total weight 17,5\%, Shareholder perspective contain 1 KPI with total weight 19,0 .
\end{abstract}

Keywords: Key Performance Indicator, Supply Chain, Balanced Scorecard, Analytical Hierarchy Processes

\section{PENDAHULUAN}

Tingkat penyebaran konsumen pada area yang cukup luas memerlukan waktu yang cukup lama bagi suatu produk untuk sampai dan digunakan oleh para konsumen. Hal ini menjadi masalah yang serius bagi jenis produk yang tidak tahan lama atau cepat rusak jika kontak langsung dengan udara, seperti aneka kue, roti, permen, snack, sabun, atau produk-produk yang tidak boleh kontak langsung dengan tangan manusia seperti obat-obatan, racun, dan berbagai jenis bahan kimia. Pengemasan dengan bahan paking dari plastik (plastic packaging) memberikan solusi terhadap permasalahan tersebut di atas.

PT. XYZ merupakan Perusahaan yang bergerak di bidang printing plastic packaging. Tingkat persaingan dan tuntutan pelanggan yang makin ketat mengharuskan Perusahaan untuk dapat memberikan produk tidak hanya berkualitas yang baik tetapi juga dalam waktu yang lebih cepat serta harga yang lebih kompetitif. Untuk mewujudkan tujuan Perusahaan tersebut, diperlukan adanya 
koordinasi lintas sektoral dari semua departemen atau organisasi yang terkait dalam suatu rantai penciptaan nilai mulai dari supplier, pabrik, jasa transportasi dan jaringan distribusi serta pelanggan.

Model pengelolaan rantai pasok yang mengintegrasikan pemasok, perusahaan dan pelanggan yang banyak digunakan oleh perusahaan adalah "Supply Chain Management” (SCM). Secara umum penerapan konsep SCM dalam Perusahaan akan memberikan manfaat, antara lain kepuasan pelanggan, meningkatkan pendapatan, menurunnya biaya, pemanfaatan aset yang semakin tinggi, peningkatan laba, dan Perusahaan semakin besar. [1].

Mengingat besarnya manfaat SCM dalam pengendalian sebuah bisnis, maka pada jurnal ilmiah ini akan membahas tentang Perancangan Key Performance Indicator (KPI) kinerja Supply Chain Perusahaan dengan pendekatan model Balanced Scorecard. Perancangan dilakukan dengan pengembangan indikatorindikator yang meliputi kinerja pada sepanjang aliran rantai suplai dengan pendekatan perspektif Balanced Scorecard, yaitu: internal proses, pertumbuhan dan pembelajaran, pelanggan dan finansial.

Indikator kinerja yang selama ini digunakan untuk mengukur kinerja Supply Chain PT. XYZ hanya dilihat dari sisi produktivitas Perusahaan. Pendekatan pengukuran seperti ini tergolong dalam model pengukuran tradisional [2]. Produktivitas hanya merupakan indikator kinerja pada bagian internal proses, sedangkan internal proses hanyalah merupakan salah satu mata rantai dari Supply Chain. Pengukuran kinerja yang dilakukan secara parsial hanya pada sisi internal proses saja tidak akan memberikan hasil yang effisien [3].

Kelemahan dari penerapan kinerja inti selama ini yang diterapkan oleh PT. XYZ adalah jika dalam penerapan pengukuran kinerja ditemukan adanya indikasi permasalahan, maka akan sangat sulit bagi manager untuk mengembangkan suatu model hubungan sebab akibat dalam penyelesaiannya. Ini karena tidak cukup tersedia data-data atau informasi yang dapat digunakan untuk menganalisis kemungkinan penyebab permasalahan tersebut. Perusahaan perlu merancang suatu model KPI supply chain secara keseluruhan dan terintegrasi dalam suatu hubungan sebab akibat, mulai dari supplier, internal proses hingga konsumen, agar dapat diketahui efektifitas pelaksanaan supply chain Perusahaan.

Berdasarkan perumusan masalah di atas, maka tujuan yang hendak dicapai adalah: mengidentifikasi KPI untuk pengukuran kinerja Supply chain, melakukan validasi terhadap KPI yang sudah berhasil diindikasikan dan memberikan usulan rancangan KPI Supply chain PT XYZ.

Indikator-indikator yang digunakan sebagai obyek ukuran kinerja disebut sebagai indikator kinerja (performance indikators). Hanya indikator-indikator kunci yang menentukan kinerja yang akan diukur. Indikator-indikator kunci ini lebih dikenal dengan nama KPI.

Supply chain adalah jaringan PerusahaanPerusahaan yang secara bersama-sama bekerja untuk menciptakan dan menghantarkan suatu produk ke tangan pemakai akhir. PerusahaanPerusahaan tersebut termasuk supplier, pabrik, distributor, retailer serta Perusahaan-Perusahaan pendukung seperti Perusahaan jasa logistik [4].

Pada suatu supply chain biasanya terdapat 3 macam aliran yang harus dikelola. Pertama, aliran barang yang mengalir dari hulu ke hilir. Kedua, aliran uang dan sejenisnya yang mengalir dari hilir ke hulu. Ketiga, aliran informasi yang bisa terjadi dari hulu ke hilir ataupun sebaliknya. Metode atau alat yang digunakan untuk mengelola Supply Chain disebut Supply Chain management (SCM). SCM merupakan integrasi dan kerjasama tidak hanya antar departemen dalam suatu Perusahaan tetapi juga dengan partner eksternal. Dalam SCM sangat diperlukan adanya sharing informasi tentang pelanggan, actual demand, nilai transaksi sales, rencana strategis Perusahaan dan lain-lain [5].

\section{Balanced Scorecard Sebagai Alat Pengukur Kinerja Supply Chain}

Balanced Scorecard diperkenalkan oleh Kaplan dan Norton pada tahun 1992. Yang 


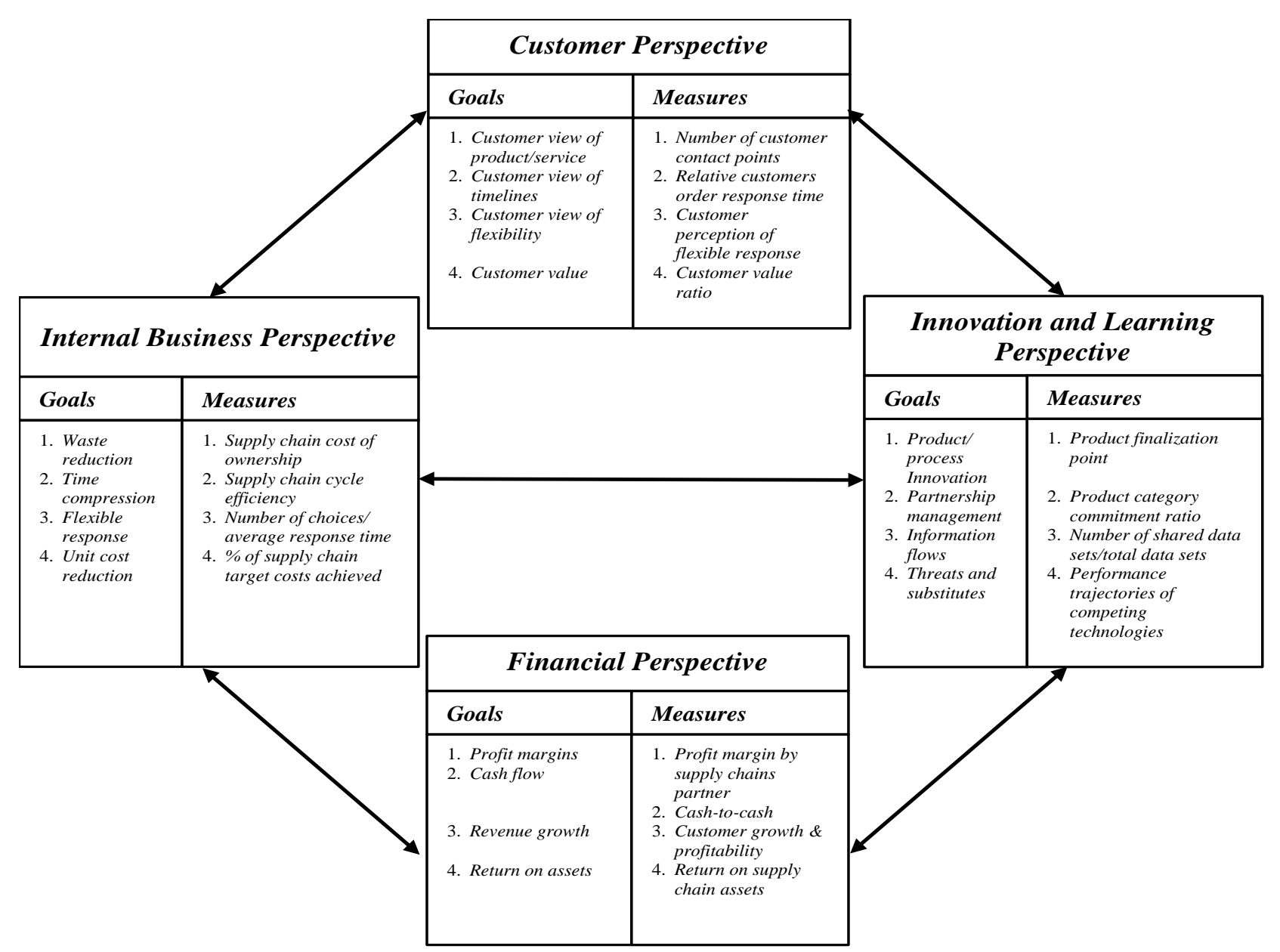

Gambar 1. Kerangka kerja SCM-BSC [5]

membedakan Balanced Scorecard dengan pengukuran konvensional adalah adanya keseimbangan antara ukuran kinerja yang digunakan, yang meliputi, keseimbangan antara unsur internal dan eksternal organisasi serta keseimbangan antara lag indicators dengan lead indicators. Pengukuran dalam Balanced Scorecard dibagi kedalam empat perspektif: Customer, Internal Business, Inovation and Learning, dan Financial Perspective. Kerangka kerja SCM-BSC dapat dilihat pada Gambar 1.

\section{Analytical Hierarchy Process (AHP)}

AHP dapat menyelesaikan masalah yang kompleks melalui penyusunan hirarki. Suatu masalah kompleks dan tidak terstruktur dipecahkan ke dalam kelompok-kelompoknya. Kemudian kelompok-kelompok tersebut diatur menjadi suatu bentuk hirarki [6]. Tahapan penyelesaian masalah dengan metode AHP yaitu: pembentukan hirarki, penentuan prioritas dan penghitungan konsistensi.

\section{METODE PENELITIAN}

Model pendekatan yang digunakan dalam perancangan key performance Indicators Supply Chain ini adalah metode Balanced Scorecard. Dari model tersebut disusun metrik-metrik indikator kinerja supply chain. Penetepan hirarki dan pembobotan dari metrik-metrik tersebut dilakukan dengan menggunakan metode Analytic Hierarchy Process. Metode pengumpulan data antara lain:

\section{Studi Lapangan}

Studi lapangan dilakukan untuk mengetahui kondisi sebenarnya di lapangan. Disini dilakukan wawancara, kuesioner dan brainstorming dengan pihak manajemen PT XYZ mengenai indikator kinerja supply chain yang di lakukan Perusahaan saat ini.

\section{Studi Pustaka}

Studi pustaka dilakukan untuk mendapatkan landasan teori yang akan menjadi 
acuan berpikir pelaksanaan kegiatan penelitian ini. Studi pustaka diperoleh dari berbagai literatur antara lain buku, website, jurnal-jurnal penelitian sejenis yang telah dilakukan sebelumnya.

\section{HASIL DAN PEMBAHASAN Mapping Sistem Supply Chain}

Mapping

dilakukan

untuk menggambarkan supply chain perusahaan sehingga dapat diketahui sistem yang berjalan mengenai lima proses inti supply chain, yaitu plan, source,make, deliver dan return. Selain itu juga dapat diketahui departemen-departemen (perusahaan-perusahaan) yang terkait di dalamnya dan juga aliran material, informasi dan uang. Gambar 2 adalah mapping SCM PT. XYZ.

\section{Mengidentifikasi Key Performance Indikator (KPI)}

Tahap ini dilakukan identifikasi KPI-KPI yang akan di gunakan sebagai ukuran keberhasilan. Identifikasi dilakukan terhadap KPI proses inti dari supply chain yaitu, KPI supplier, KPI internal, KPI costumer, KPI financial. Dari hasil studi literatur seperti buku, jurnal, ulasan dari website serta brainstorming dengan manajemen Perusahaan teridentifikasi 24 KPI dalam 4 perspektif indikator SCM sebagai berikut :

- Perspektif Supplier facing: prosentase material reject, supplier cycle time, supplier delivery performance, dan respon terhadap material retur.

- Internal Facing: production waste: cost of good sold, productivity (meter/man-hours), Inventory days of supply, overall effectiveness equipment (OEE), prosentase turnover karyawan, jumlah kecelakaan kerja, jumlah jam training per karyawan, dan tingkat ketidakhadiran karyawan.

Customer Facing terdiri dari: posentase produk return, Order fulfillment lead time, delivery performance, respon terhadap produk return, respon terhadap keluhan pelanggan, new customer, customer retention dan index kepuasan pelanggan.

Shareholder facing terdiri dari EBIT, ROTA dan EVA

\section{Validasi KPI}

Identifikasi yang telah dilakukan validasi terhadap pihak Perusahaan. Validasi dilakukan dengan melalui penyebaran kuesioner ke Perusahaan dalam hal ini adalah PT. XYZ. Kuesioner dilakukan dengan sample purposive berjumlah 25 karyawan. Format yang digunakan untuk kuesioner menggunakan format linkert, hasil kuesioner ini berupa validasi (persetujuan atau ketidaksetujuan) terhadap identifikasi KPI yang diajukan serta kemungkinan tambahan KPI baru. Untuk mengukur validitas hasil kuesioner digunakan metode Product Moment Correlation Pearson

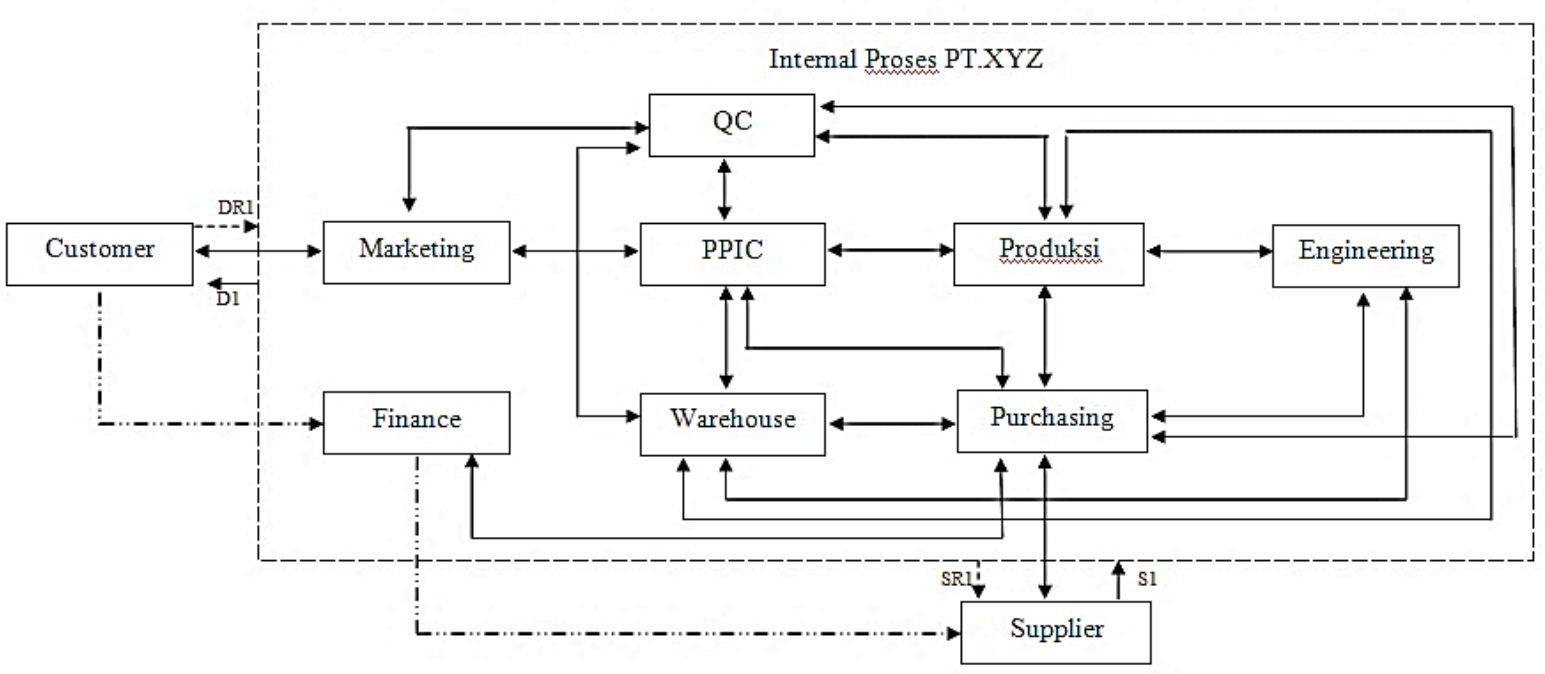

Gambar 2. Maping SCM PT XYZ 
(r). Rumus korelasi product moment adalah sebagai berikut [6]:

$r=\frac{\mathrm{N} \sum \mathrm{XY}-\left(\sum \mathrm{X}\right)\left(\sum \mathrm{Y}\right)}{\sqrt{\mathrm{N} \sum \mathrm{X}^{2}-\left(\sum \mathrm{X}\right)^{2}} \sqrt{\mathrm{N} \sum \mathrm{Y}^{2}-\left(\sum \mathrm{Y}\right)^{2}}}$

Dimana:

$$
\begin{array}{rll}
\mathrm{X} & \text { : skor individual } \\
\mathrm{Y} & \text { : total skor untuk masing-masing } \\
& \text { responden. } \\
\mathrm{N} & \begin{array}{l}
\text { adalah jumlah } \\
\text { pengamatan }
\end{array}
\end{array}
$$

Pengujian reliabilitas digunakan rumus Rulon, yaitu dengan membandingkan varians perbedaan skor dengan varians total, adapun rumusnya adalah sebagai berikut [6]:

$r_{x x \prime}=1-\frac{S D b^{2}}{S D t^{2}}$

\section{Dimana:}

$$
\begin{array}{ll}
r_{X x^{\prime}} & : \text { Koefisien reliabilitas } \\
S D b^{2} & : \text { Varians perbedaan skor belahan } \\
S D t^{2} & : \text { Varians skor Total }
\end{array}
$$

Rumus untuk menghitung varians adalah sebagai berikut [6]:

$S D x^{2}=\frac{\sum X^{2}-\frac{\left(\sum X\right)^{2}}{N}}{N}$

KPI hasil validasi dan reliability adalah sebagi berikut:

- Perspektif Supplier facing: prosentase material rejects, supplier cycle time dan supplier delivery performance

- Internal Facing: production waste, cost of good sold, productivity (meter/man-hours), inventory days of supply, overall efectiveness equipment (OEE), prosentase turnover karyawan, jumlah kecelakaan kerja, jumlah jam training per karyawan, tingkat ketidakhadiran karyawan, aged Inventory, customer facing, prosentase produk return, delivery performance, respon terhadap produk return, new customer, customer retention, dan index kepuasan pelanggan

\section{Shareholder Facing: EBIT}

Hasil validasi menunjukkan adanya pengurangan jumlah KPI menjadi 20 KPI dari rancangan yang diajukan sebelumnya sebanyak 24 KPI. KPI yang dihilangkan adalah respon terhadap keluhan pelanggan, order fulfillment lead time, ROTA dan EVA.

\section{Kerangka kerja Supply Chain}

Desain kerangka kerja Suppply chain. PT. XYZ seperti pada Gambar 3. Keberhasilan supply chain dalam mencapai tujuannya antara lain menekan reject, memperkecil cycle time, menurunkan aged inventory, meningkatkan produktifitas, akan berimbas secara internal yaitu menurunkan tingkat pemborosan sehingga akan meningkatkan pendapatan perusahaan dan secara ekternal akan memberikan nilai tambah kepada pelanggan yang berupa kualitas produk yang baik, serta delivery yang tepat waktu.

Keuntungan yang dirasakan pelanggan mempengaruhi tingkat kepuasan pelanggan, sehingga perusahaan dapat mempertahankan pelanggan atau bahkan bertambah jumlah pelanggan baru. Hal ini membawa konsekuensi logis pada peningkatan penjualan perusahaan sehingga pendapatan perusahaan meningkat.

Perbaikan finansial yang dialami oleh perusahaan sebagai akibat dari tercapainya tujuan supply chain serta kepuasan pelanggan memotivasi perusahaan untuk selalu melakukan proses perbaikan.

\section{Kerangka kerja Balanced Scorecard}

Ada keterkaitan yang kuat antara kerangka kerja supply chain dengan kerangka kerja balanced scorecard. Desain kerangka kerja balanced scorecard PT. XYZ seperti pada Gambar 4.

Perspektif pelanggan menggunakan ukuran berapa nilai yang diberikan kepada pelanggan dilihat dari segi waktu, kualitas, performansi layanan, dan biaya. Untuk mencapai tujuan ini dilakukan melalui perbaikan pada pespektif internal proses juga perspektif pertumbuhan dan pembelajaran.

Perspektif internal Business process digunakan untuk mengevaluasi seberapa besar tingkat ekspektasi yang diharapkan pelanggan serta shareholder dapat terpenuhi melalui 
perbaikan proses di internal organisasi tersebut. Untuk mencapai tujuan ini perlu didukung oleh perbaikan ada perspektif pertumbuhan dan pembelajaran.

\section{Tahap Pembobotan}

Tahap pembobotan ini dilakukan dengan Analytical Hierarchy Process (AHP), adapun langkah-langkahnya sebagai berikut: melakukan perbandingan berpasangan antar KPI dan menghitung bobot dan rasio konsistensi

\section{Melakukan Perbandingan Berpasangan Antar KPI}

Untuk memudahkan pemahaman, misalkan jumlah elemen yang dipasangkan ada empat buah, maka matrix perbandingan berpasangan sebagai berikut:

Tabel 1. Matrix Perbandingan Berpasangan

\begin{tabular}{ccccc}
\hline $\begin{array}{c}\text { Kriteria atau } \\
\text { Alternatif }\end{array}$ & 1 & 2 & 3 & 4 \\
\hline 1 & $\mathrm{X}_{11}$ & $\mathrm{X}_{12}$ & $\mathrm{X}_{13}$ & $\mathrm{X}_{14}$ \\
2 & $\mathrm{X}_{21}$ & $\mathrm{X}_{22}$ & $\mathrm{X}_{23}$ & $\mathrm{X}_{24}$ \\
3 & $\mathrm{X}_{31}$ & $\mathrm{X}_{32}$ & $\mathrm{X}_{33}$ & $\mathrm{X}_{34}$ \\
4 & $\mathrm{X}_{41}$ & $\mathrm{X}_{42}$ & $\mathrm{X}_{43}$ & $\mathrm{X}_{44}$ \\
\hline
\end{tabular}

Dimana, Xij adalah skor individual perbandingan berpasanga kriteria i terhadap kriteria j.

Untuk mengisi matrik perbandingan berpasangan itu, digunakan bilangan untuk menggambarkan relatif pentingnya suatu elemen di atas yang lainnya, berkenaan dengan sifat tersebut. Tabel 2 memuat skala perbandingan berpasangan.

Skala itu mendefinisikan dan menjelaskan nilai 1 sampai dengan 9 yang ditetapkan bagi pertimbangan dalam membandingkan pasangan elemen yang sejenis di setiap tingkat hirarki terhadap suatu kinerja yang berada setingkat di atasnya.

Untuk memperoleh peringkat prioritas menyeluruh bagi suatu persoalan keputusan, kita harus menyatukan atau mensitesis pertimbangan yang dibuat dalam melakukan perbandingan berpasangan yaitu dengan melakukan suatu pembobotan untuk menunjukan prioritas setiap elemen.

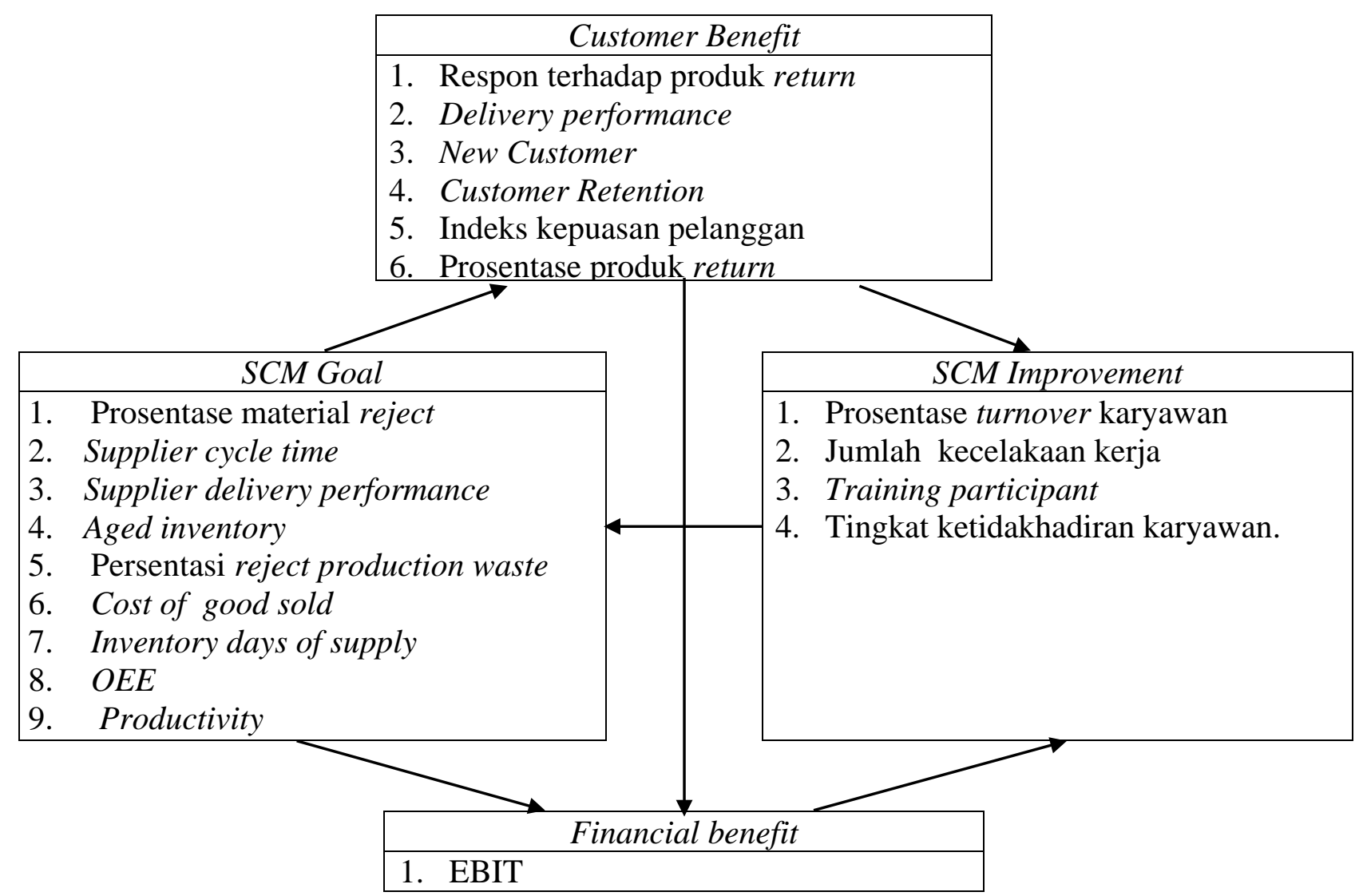

Gambar 3. Kerangka Kerja Supply Chain PT. XYZ 


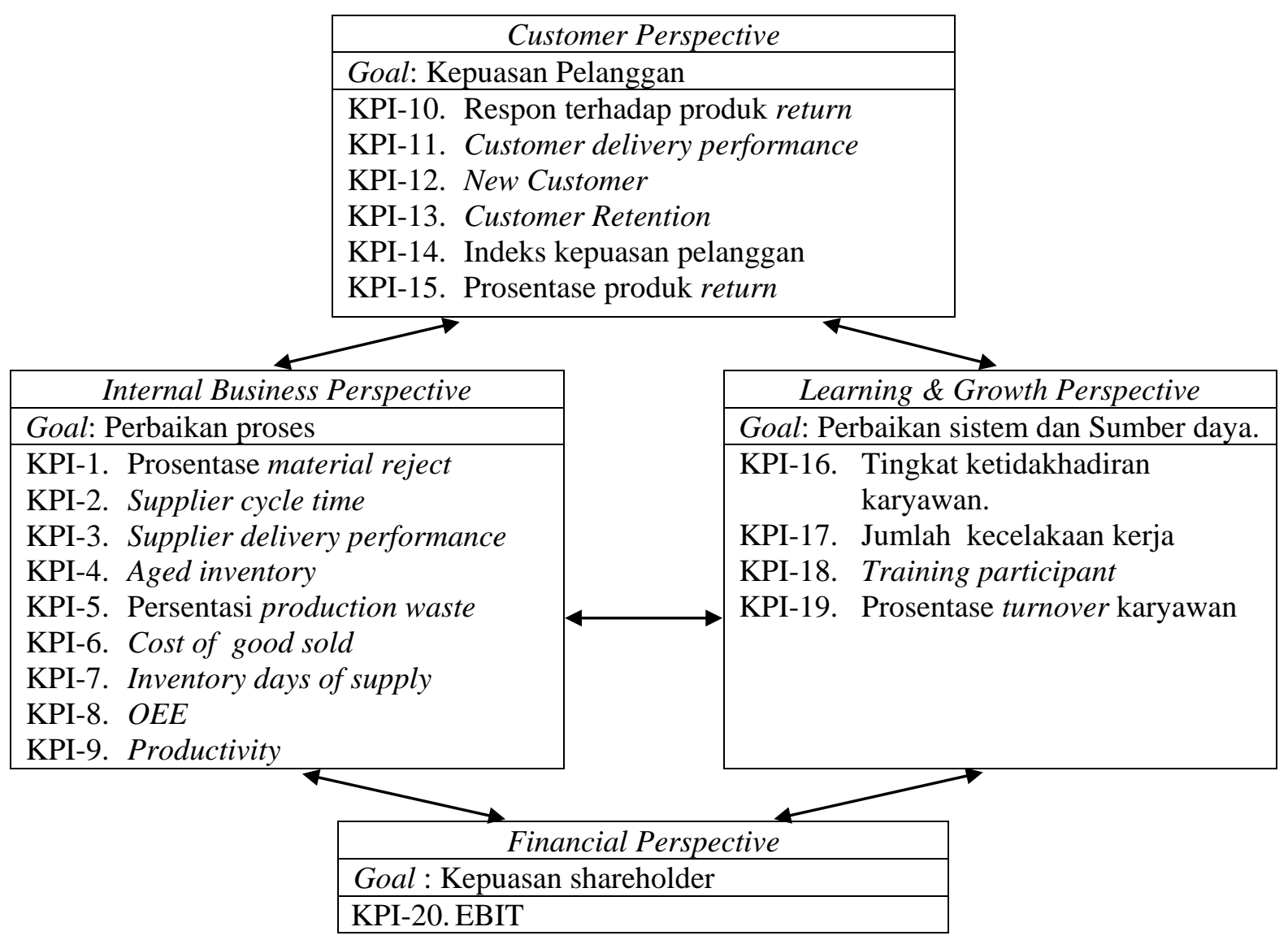

Gambar 4. Kerangka Kerja Balanced Scorecard PT. XYZ

Tabel 2. Skala Dasar pada Perbandingan Berpasangan [7]

\begin{tabular}{|c|c|c|}
\hline $\begin{array}{c}\text { Tingkat } \\
\text { Kepentingan }\end{array}$ & Penjelasan & Keterangan \\
\hline 1 & Kedua elemen sama pentingnya & $\begin{array}{l}\text { Dua elemen mempunyai pengaruh yang sama besar terhadap } \\
\text { tujuan. }\end{array}$ \\
\hline 3 & $\begin{array}{l}\text { Elemen yang satu sedikit lebih } \\
\text { penting dari elemen lainnya }\end{array}$ & $\begin{array}{l}\text { Pengalaman dan penilaian sedikit menyokong satu elemen } \\
\text { dibandingkan elemen lainnya. }\end{array}$ \\
\hline 5 & $\begin{array}{l}\text { Elemen yang satu lebih penting dari } \\
\text { elemen lainnya }\end{array}$ & $\begin{array}{l}\text { Pengalaman dan penilaian sangat kuat menyokong satu } \\
\text { elemen dibandingkan elemen lainnya. }\end{array}$ \\
\hline 7 & $\begin{array}{l}\text { Elemen yang satu sangat lebih } \\
\text { penting dari elemen lainnya }\end{array}$ & $\begin{array}{l}\text { Satu elemen yang kuat disokong dan dominan terlihat dalam } \\
\text { praktek }\end{array}$ \\
\hline $2,4,6,8$ & $\begin{array}{l}\text { Apabila ragu - ragu antara dua nilai } \\
\text { yang berdekatan. }\end{array}$ & Nilai ini diberikan bila ada dua kompromi di antara pilihan \\
\hline $1 /(1-9)$ & \multicolumn{2}{|c|}{ Kebalikan nilai tingkat kepentingan dari skala 1-9. } \\
\hline Kebalikan & \multicolumn{2}{|c|}{$\begin{array}{l}\text { Jika untuk aktivitas mendapatkan satu angka dibanding dengan aktivitas j, maka j mempunyai nilai } \\
\text { kebalikannya dibanding dengan i }\end{array}$} \\
\hline
\end{tabular}

\section{Menghitung bobot}

Hasil

berpasangan

pengisian

kemudian

perbandingan

diolah untuk

menentukan bobot pada setiap kriteria dalam

menentukan alternatif keputusan. Suatu pendekatan alternatif yang sederhana untuk memperoleh prioritas menggunakan langkahlangkah berikut [6]. Sebelumnya hitung jumlah total nilai perbandingan setiap kolom $\left(\sum \mathbf{X}_{\mathrm{ij}}\right)$
Tabel 3. Menghitung nilai $\sum X_{i j}$

\begin{tabular}{ccccc}
\hline $\begin{array}{c}\text { Kriteria atau } \\
\text { Alternatif }\end{array}$ & 1 & 2 & 3 & 4 \\
\hline 1 & $\mathrm{X}_{11}$ & $\mathrm{X}_{12}$ & $\mathrm{X}_{13}$ & $\mathrm{X}_{14}$ \\
2 & $\mathrm{X}_{21}$ & $\mathrm{X}_{22}$ & $\mathrm{X}_{23}$ & $\mathrm{X}_{24}$ \\
3 & $\mathrm{X}_{31}$ & $\mathrm{X}_{32}$ & $\mathrm{X}_{33}$ & $\mathrm{X}_{34}$ \\
4 & $\mathrm{X}_{41}$ & $\mathrm{X}_{42}$ & $\mathrm{X}_{43}$ & $\mathrm{X}_{44}$ \\
\hline Total & $\Sigma \mathrm{X}_{\mathrm{i} 1}$ & $\Sigma \mathrm{X}_{\mathrm{i} 2}$ & $\Sigma \mathrm{X}_{\mathrm{i} 3}$ & $\Sigma \mathrm{X}_{\mathrm{i} 4}$ \\
\hline
\end{tabular}


Tabel 4. Menghitung nilai Bobot Prioritas

\begin{tabular}{|c|c|c|c|c|c|}
\hline $\begin{array}{l}\text { Kriteria atau } \\
\text { Alternatif }\end{array}$ & 1 & 2 & 3 & 4 & Rata-Rata (Bobot Prioritas) \\
\hline 1 & $\frac{\mathrm{X}_{11}}{\sum \mathrm{X}_{\mathrm{i} 1}}$ & $\frac{X_{12}}{\Sigma X_{i 2}}$ & $\frac{X_{13}}{\Sigma X_{i 3}}$ & $\frac{X_{14}}{\Sigma X_{i 4}}$ & P1 \\
\hline 2 & $\frac{\mathrm{X}_{21}}{\sum \mathrm{X}_{\mathrm{i} 1}}$ & $\frac{X_{22}}{\Sigma X_{i 2}}$ & $\frac{X_{23}}{\Sigma X_{i 3}}$ & $\frac{X_{24}}{\Sigma X_{i 4}}$ & P2 \\
\hline 3 & $\frac{\mathrm{X}_{31}}{\sum \mathrm{X}_{\mathrm{i} 1}}$ & $\frac{X_{32}}{\Sigma X_{i 2}}$ & $\frac{X_{33}}{\Sigma X_{i 3}}$ & $\frac{X_{34}}{\Sigma X_{i 4}}$ & P3 \\
\hline 4 & $\frac{\mathrm{X}_{41}}{\sum \mathrm{X}_{\mathrm{i} 1}}$ & $\frac{\mathrm{X}_{33}}{\sum \mathrm{X}_{\mathrm{i} 2}}$ & $\frac{\mathrm{X}_{43}}{\sum \mathrm{X}_{\mathrm{i} 3}}$ & $\frac{\mathrm{X}_{44}}{\sum \mathrm{X}_{\mathrm{i} 4}}$ & P4 \\
\hline
\end{tabular}

Dimana : $\mathrm{P}$ adalah rata-rata bobot kriteria

Hitung jumlah rasio antara Xij: $\Sigma \mathrm{X}_{\mathrm{i} 1}$ dan selanjutnya hitung rata-rata nilai pada setiap baris. Nilai inilah yang menjadi bobot prioritas setiap kriteria atau alternatif

Dari hasil perhitungan bobot untuk masing-masing perspektif Balanced Scorecard serta KPI yang bersesuaian adalah seperti pada Tabel 5.

Tabel 5. Bobot Perspective dan KPI

\begin{tabular}{ll}
\hline Perspektif (Bobot-\%) & KPI (bobot-\%) \\
\hline & KPI-1 (0.8) \\
& KPI-2 (1.1) \\
& KPI-3 (1.4) \\
& KPI-4 (2.7) \\
Internal (21.0) & KPI-5 (3.0) \\
& KPI-6 (2.4) \\
& KPI-7 (2.4) \\
& KPI-8 (2.8) \\
& KPI-9 (4.2) \\
\hline & KPI-10 (2.9) \\
& KPI-11 (7.7) \\
& KPI-12 (3.5) \\
Customer (42.6) & KPI-13 (4.5) \\
& KPI-14 (13.3) \\
& KPI-15 (11.1) \\
\hline & KPI-16 (2.1) \\
& KPI-17 (2.8) \\
Learning \& growth (17.5) & KPI-18 (5.9) \\
& KPI-19 (6.6) \\
\hline Shareholder (19.0) & KPI-20 (19.0) \\
\hline
\end{tabular}

KESIMPULAN

Dari hasil analisis dan pembahasan dapat disimpulkan bahwa identifikasi KPI Supply Chain PT XYZ teridentifikasi 24 KPI dalam 4 perspektif indikator SCM. Dari 24 KPI yang teridentifikasi diuji validitasnya dengan metode
Product Moment Correlation Pearson (r), serta dikaukan pengujian reliabilitas dengan menggunakan rumus Rulon. Hasil validasi menunjukkan adanya pengurangan jumlah KPI menjadi 20 KPI. KPI yang dihilangkan adalah respon terhadap keluhan pelanggan, Order fulfillment lead time, ROTA dan EVA. Dari 20 KPI yang lolos uji validasi dilakukan pembobotan dengan metode Analitycal Hierarchy Process (AHP).

\section{DAFTAR PUSTAKA}

[1] Bozarth dan Handfield, 2008, "Introduction to Operations and Supply Chain Management", Pearson Education, Inc., New Jersey, United State.

[2] Gunasekaran, at al, 2004; “A Framework for Supply Chain Performance Measurement”, Int. J. Production Economic.87, Arkansas, USA.

[3] Budiarti, 2007, "Evaluasi Kinerja Bisnis Dengan Pendekata Balanced Scorecard pada PT. Poliplas Makmur Santosa Ungaran., Skripsi”, FE Jurusan Akutansi, Semarang.

[4]. I Nyoman Pujawan, 2005, Supply Chain Management, edisi 1, Guna Widya

[5] Brewer dan Speh, 2000, "Using Balanced Scorecard to Measure Supply Chain Performance", ABI/INFORM Global, Journal of Business Logistic Vol. 21, No.1.

[6]. Erni, 2009; "Productivity Measurement Using Omax and Fuzzy Logic at PT. 
Perancangan Key Performance Indicators Kinerja Supply Chain PT. XYZ dengan Pendekatan Balanced Scorecard Joko Hardono

AMD”, Industrial Engineering Department. Indonusa Esa Unggul University, Indonesia.

[7] Dianawati dan Panggalo, 2009, ”Pengukuran Dan Analisis Nilai Overall Equipment Efectiveness Sebagai Dasar Perbaikan Sistem Manufacture Pipa Baja”, Jurusan Mesin dan Industri FT UGM, ISBN 978-979-18528-1-4, Yogyakarta 